\title{
ANALYSIS OF DISTRIBUTION EFFICIENCY ON BOTTLED WATER PRODUCT USING DATA ENVELOPMENT ANALYSIS METHOD
}

\author{
Harimurti Bambang Samudra, Master of Management and Business \\ Business School, IPB University, Indonesia \\ Sumarwan Ujang, Simanjuntak Megawati \\ Department of Family and Consumer Sciences, Faculty of Human Ecology, \\ IPB University, Indonesia \\ *E-mail: harimurti@samudra.id
}

\begin{abstract}
Every industry requires efficient marketing distribution to help end customers get their products more easily and optimize the profit to achieve a large market share. As a Stateowned Enterprise, Perum Jasa Tirta II (PJT II) faces a great challenge in distributing localbrand bottled water products. This study aims to identify the distribution channel of bottled water product used by PJT II, analyze the efficiency level of the distribution, and formulate the improvement strategy using Data Envelopment Analysis (DEA) method with the help of Frontier Analysis Software. The limits of the efficiency measurement used in this study are the input and output variables. Input variables include the number of agents, delivery volume, and distribution cost. Output variables include the volume of sales, revenue, and profits. This study concludes that: the distribution channel in use is the zero-level and one-level distribution channel; there is only one area in which the distribution channel runs efficiently: Purwakarta. Meanwhile, distribution channels in the other six areas (Jakarta, Bandung, Karawang, Subang, Bekasi, and Tangerang) are inefficient; strategies that can be implemented to improve the inefficient distribution channels are: reducing the volume of delivery to match the targeted efficiency level, increasing the volume of sales based on the targeted efficiency level in order to avoid inventory pileup and boost profit; and Increasing the number of retailers in the areas in which the distribution is not efficient.
\end{abstract}

\section{KEY WORDS}

Distribution, channels, efficiency, data envelopment analysis.

Food and beverage industry is a downstream industry deriving from Agriculture. Indonesia, populated by approximately 237.6 million people, with $1.49 \%$ population growth rate, provides a potential market for it. As these numbers are expected to keep growing, the need for food and water will only triplicate, and the future for the industry is promising. Bottled water or packaged water is one of the most pervasive commodities in the industry. Water is a basic human need. While in most of the developed countries the government has succeeded in providing access to clean drinking water in the form of tap water, developing countries' residents such as Indonesians have to rely on bottled water as their primary drinking source.

In the past decades, the consumption of bottled water has been rising sharply, and so has the growth of bottled water industry. According to Sulaeman (2015), there are about 500 companies specializing in selling Air Minum Dalam Kemasan or AMDK (bottled water) in Indonesia. They are divided into two categories: small-scale or local-scale companies and large-scale companies which dominate the national market. Based on research conducted by Goldman Sachs in 2015, Aqua from Danone Group controls 46.7\% of market share in the industry, followed by Tirta Bahagia (Club) with 4\%, Tangmas (2 Tang) with $2.8 \%$, PT Santa Rosa Indonesia (Oasis) with 1.8\%, Triusaha Mitraraharja (Super O2) with 1.7\%, and Sinar Sosro (Prima) with 1.4\%. Local-scale companies take up the rest of $41.60 \%$. 
Table 1 - Market Share in Bottled Water Industry

\begin{tabular}{ccc}
\hline No & Company & Market Share \\
\hline 1 & Danone Group & $46.70 \%$ \\
2 & Local Brand Product & $41.60 \%$ \\
3 & Tirta Bahagia & $4.00 \%$ \\
4 & Tangmas & $2.80 \%$ \\
5 & Santa Rosa Indonesia & $1.80 \%$ \\
6 & Triusaha Mitraraharja & $1.70 \%$ \\
7 & Sinar Sosro & $1.40 \%$ \\
\hline
\end{tabular}

As can be deduced from the situation explained above, local brands are confronted with a great challenge in their marketing, especially with the ruthless competition against the large-scale and multinational companies (Hidayati 2016). One of the efforts that can tip the scale in their favor is implementing marketing management in order to gain more market share. Marketing is the end process of production activities, which determines the value and price of goods produced that ensure the company sustainability and generate wealth for the producers (Wibowo 2016). While Simamora (2003) said that marketing management is an activity performed by individuals or groups that encourages the exchange of goods or services to meet the satisfaction of consumers and bring profit to the organization.

In marketing management, there are several strategies that can be employed to win a market competition, one of which is by using the "place" element of the marketing mix or, in other words, distribution. To gain market share, every agro-industry needs an efficient distribution. Saladin (1996) stated that distribution channel refers to a business structure of an organization that performs all activity needed to transfer products from producers to customers. The selection of a suitable and efficient distribution channel will result in the customers getting their products more easily (Stanton 1993).

One of State-owned Enterprises (BUMN) in Indonesia that sells local-brand bottled water (AMDK) and distributes it to various areas is Perum Jasa Tirta II (PJT II). They go by the brand "Jatiluhur" and produce and pack water in different sizes such as cup, bottle, and gallons. Until 2019, a number of cities determined to be the selling point of PJT II are Purwakarta, Bandung, Bekasi, Tangerang, Depok, Bogor, and Jakarta. In an industry where a large portion of market share is claimed by mega companies, efficient distribution is a must for PJT II, because it will affect other marketing decisions to ensure that the company thrives.

\section{METHODS OF RESEARCH}

This study was conducted at the Head Office of PJT II located at Jalan Lurah Kawi Number 1, Jatiluhur, Purwakarta Regency, West Java. This location was selected to fit the purpose and characteristics of the research regarding the distribution efficiency of AMDK marketing. Respondents were picked using purposive technique and research information was collected through a key informant (information source) who is the General Manager of Tourism and AMDK of Perum Jasa Tirta II.

The data in this study are collected through interviews, observation, and documentation. The types of data used are primary and secondary data. The method of data analysis selected for this research are: (1) Descriptive data analysis, used to identify the distribution channel of AMDK; and (2) Quantitative data analysis, which is done by classifying, comparing, and calculating numeric data using the Data Envelopment Analysis (DEA) method with the help of Frontier Analysis Software.

The procedures of the analysis are as follows:

- Determining the Decision Making Unit (DMU). The DMU in this research is the areas that become the destination of the AMDK distribution channel, namely Jakarta, Bandung, Subang, Karawang, Bekasi, and Purwakarta. Each DMU will be compared to each other to distinguish which is the most efficient;

- Identifying Input and Output Variables. Input and output variables in this research are determined based on the interview with respondents and also previous research. Input variables are the resources used to carry out all function in the AMDK 
distribution process, whereas output variables are the result of the distribution activity. Input variables include the number of agents, delivery volume, and distribution cost. Output variables include the volume of sales, revenue, and profits;

- Testing Correlation Factor. Correlation factor test is intended to establish the connection between two variables, where the value of one variable may be dependent on the other. This test is performed using SPSS Software. This research uses Bivariate Correlation and the parameter is the Pearson Correlation Coefficient, which returns a value between -1 and 1 , where 1 indicates a strong positive relationship. The larger the coefficient of one variable is, the stronger the connection it has with other variables compared to it. The coefficient interval illustrating the level of connection is shown below in Table 2 .

Table 2 - Coefficient Interval

\begin{tabular}{cc}
\hline Coefficient Interval & Connection Level \\
\hline $0.000-0.199$ & Very Low \\
$0.200-0.399$ & Low \\
$0.400-0.599$ & Moderate \\
$0.600-0.799$ & Strong \\
$0.800-1.000$ & Very Strong \\
\hline
\end{tabular}

Data Envelopment Analysis (DEA) is used to assess how efficient is a DMU in utilizing its resources to produce maximum output (Ray 2004). This research applies the input-output orientation model and the Variable-Return-To-Scale DEA model, with the assumption that every addition of input does not yield proportional output, so that the efficiency level can either increase or decrease. This model was chosen because the AMDK distribution investigated in this study is not yet optimal. The efficiency score is limited from 0 to $100 \%$, with $100 \%$ indicating a perfect efficiency level and $0 \%$ indicating the lowest. There are three conditions in the DEA result as shown below.

Table 3 - Efficiency Condition Based on DEA Result

\begin{tabular}{|c|c|c|c|c|}
\hline No & $\begin{array}{l}\text { Range } \\
\text { Condition }\end{array}$ & Score & Efficiency & Explanation \\
\hline 1 & Range Red & $0-89.99$ & Inefficient & $\begin{array}{l}\text { High-risk projects because it is far from the expected score; } \\
\text { management action is necessary. }\end{array}$ \\
\hline 2 & $\begin{array}{l}\text { Range } \\
\text { Amber }\end{array}$ & $90-99.99$ & Inefficient & $\begin{array}{l}\text { Moderate-risk project; risky if outstanding problems are not } \\
\text { immediately addressed; management concern is necessary. }\end{array}$ \\
\hline 3 & $\begin{array}{l}\text { Range } \\
\text { Green }\end{array}$ & 100 & Efficient & $\begin{array}{l}\text { Low-risk project because it meets the expected score. There are } \\
\text { two efficiency orientations: } \\
\text { - Efficiency and output orientation increases when input stays } \\
\text { constant or output stays constant when input decreases; } \\
\text { Efficiency from input orientation, which is where input stays } \\
\text { constant when output decreases or input decreases when input } \\
\text { stays constant. }\end{array}$ \\
\hline
\end{tabular}

After implementing DEA method to pinpoint the inefficient distribution channel, the next step is formulating an improvement strategy to make them more efficient. The strategy is created using Frontier Analysis Software. It will show the actual level, targeted level, and percentage of improvement of both input and output variables. Subsequently, it can be figured out which variable needs to be improved, whether by minimizing the input or optimizing the output to achieve the preferred efficiency.

\section{RESULTS AND DISCUSSION}

Perum Jasa Tirta II is a State-owned Enterprise (BUMN) founded in accordance with Government Regulation Number 7 the Year 2010. Essentially, the core business of PJT II is to manage raw water and clean water in the area of West Java, DKI Jakarta, and Banten, and to operate Jatiluhur Hydroelectric Power Plant. But as the business expands, PJT II 
started producing bottled water (AMDK) and began constructing the warehouses in 2009. The product, going by the brand "Jatiluhur", was first introduced to the market in 2013. The brand claims to be "De-mineral Water" which means mineral concentration found in the water is slightly less than in other regular product. "Jatiluhur" also claims that the water is healthier and gives a refreshing sensation when consumed. PJT II owns several AMDK production unit situated in the vicinity of Jatiluhur Dam in Purwakarta and has distribution network in five big cities like Jakarta, Bandung, Bekasi, Subang, and Karawang. Consumers of Jatiluhur AMDK are a number of corporations and government institutions.

To market and sell AMDK Jatiluhur, PJT II opts for two kinds of distribution channels: zero-level and one-level. According to Kotler (2009), zero-level distribution channel is the simplest type and has the shortest route since no intermediaries are involved. Producers or manufacturers sell the product directly to the customers. Customers of AMDK Jatiluhur usually come to the warehouse and make the purchase on-site. The advantage offered by this type of distribution is that payment is always made in cash. However, this zero-level distribution channel contributes only $10 \%$ to the whole sales. Furthermore, there are also some drawbacks. First, the price presented to customers is different from the price presented to retailers. Second, the market share gained by using this distribution channel cannot grow because most of these direct customers are local residents.

In one-level distribution channel, producers transfer the goods to retailers or agents who in turn sell the goods to the customers. The warehouses of AMDK Jatiluhur, as the producers, deliver the products to the retailers who have ordered in advance, taking into account distribution cost and the amount of product delivered. The delivery process takes place once in a month, based on the order made in every distribution area. The advantage offered by this type of distribution is that the price presented to retailers is higher, so is the volume of sales. It also can cover a larger area of distribution by reaching retailers outside of Purwakarta, which in turn will extend the market share. However, the deferred payment system proves to be the drawback of this distribution type, because there is a delay in the revenue earning.

Distribution efficiency occurs when optimum distribution result is attained using available resources in a specific period of time (Wirapati in Setyo Budi 2010). Distribution Efficiency Analysis is applied to analyze the distribution channel used by a company. This analysis aims to identify the level of efficiency in every distribution channel area so that it can give a constructive strategy to improve any inefficiency.

Decision-Making Unit (DMU) is a collection of individuals who participate in making the decision to manage input resources in order to generate output (Pratiwi 2009). DMU is used to determine which unit is to be measured in the Distribution Efficiency Analysis. There are seven distribution areas used in this study, and the DMU of each area can be seen in Table 4 below.

Preliminary data collection shows that there are seven DMUs in this industry. Therefore, the data are considered sufficient to be used in the efficiency analysis. The DMUs are classified to represent the object of research for each distribution area and make the efficiency calculation easier.

Table 4 - AMDK Jatiluhur Distribution Areas

\begin{tabular}{ccc}
\hline \hline Number & Distribution Areas & DMU \\
\hline \hline 1 & Jakarta & DMU-1 \\
2 & Bandung & DMU-2 \\
3 & Purwakarta & DMU-3 \\
4 & Karawang & DMU-4 \\
5 & Subang & DMU-5 \\
6 & Bekasi & DMU-6 \\
7 & Tangerang & DMU-7 \\
\hline
\end{tabular}

Input and output variables in this research are identified through direct interviews with respondents and from a literature study. Input variable is determined based on the resources that affect the performance of every DMUs. Meanwhile, output variable is determined based 
on the performance result of every DMUs. There are three input variables and three output variables in this agro-industry, which are fewer than the number of the DMU itself. Input variables include the number of agents, delivery volume, and distribution cost. Output variables include the volume of sales, revenue, and profits. The identification of input and output variables are shown below in Table 5 and the data of those variables in one month are shown in Table 6.

Table 5 - Input and Output Variable

\begin{tabular}{cccc}
\hline & Symbol & Variables & Units \\
\hline Input & X1 & Number of Agents & Outlet \\
& X2 & Delivery Volume & Carton \\
& X3 & Distribution Cost & Rupiah \\
Output & X1 & Sales Volume & Carton \\
& X2 & Revenue (Sales) & Rupiah \\
& X3 & Profit & Rupiah \\
\hline
\end{tabular}

Table 6 - Data of Input and Output Variable in One Month

\begin{tabular}{cccccccc}
\hline No & DMU & $\begin{array}{c}\text { Number } \\
\text { Agent }\end{array}$ & $\begin{array}{c}\text { Distribution } \\
\text { Volume }\end{array}$ & $\begin{array}{c}\text { Distribution } \\
\text { Cost }\end{array}$ & $\begin{array}{c}\text { Sales } \\
\text { Volume }\end{array}$ & $\begin{array}{c}\text { Revenue } \\
\text { (total sales) }\end{array}$ & Profit \\
\hline 1 & Jakarta & 34 & 7.800 & 7.544 .067 & 6.500 & 150.831 .343 & 18.105 .761 \\
2 & Bandung & 25 & 8.000 & 8.704 .693 & 7.500 & 174.093 .857 & 20.891 .263 \\
3 & Purwakarta & 20 & 9.000 & 9.865 .319 & 8.500 & 197.306 .371 & 23.676 .765 \\
4 & Karawang & 14 & 3.900 & 3.597 .940 & 3.100 & 71.958 .794 & 8.635 .055 \\
5 & Subang & 15 & 4.100 & 2.901 .564 & 2.500 & 58.031 .286 & 6.953 .754 \\
6 & Bekasi & 12 & 2.100 & 1.915 .032 & 1.650 & 38.300 .649 & 4.596 .078 \\
7 & Tanggerang & 10 & 1.500 & 3.422 .128 & 1.240 & 27.152 .115 & 1.132 .114 \\
\hline
\end{tabular}

Correlation factor test is intended to establish the statistical relationship between two variables. By performing this test, it is expected to minimize errors in the input and output data entry. The test is done using SPSS 17 software, applying Bivariate Correlation with following coefficient interval parameter: (1) 0,000 - 0,199 denoting very low connection; (2) 0,200 - 0,399 denoting low connection; (3) 0,400 - 0,599 denoting moderate connection; (4) 0,600 - 0,799 denoting strong connection; and (5) 0,800 - 1,000 denoting very strong connection. The result taken from the test demonstrating the connection between input and output variable is shown below in Table 7.

Pearson Coefficient between the input and output variables is $0,800-1,000$. This demonstrates a very strong relationship between them. The significance value (2-tailed) of 0,00 also shows a significant connection, as it still falls below 0,05. Given the positive (+) correlation coefficient, the correlation that occurs is linear. In conclusion, it can be stated that the input and output variables have a strong, significant, and positive correlation.

Table 7 - Input and Output Variable Correlation Test

\begin{tabular}{|c|c|c|c|c|}
\hline$n / n$ & Correlation Test Results & Sales Volume & $\begin{array}{c}\text { Revenue } \\
\text { (Total Sales) }\end{array}$ & Profit \\
\hline Number of Agent & $\begin{array}{l}\text { Pearson Correlation Sig. (2-tailed) } \\
\text { N }\end{array}$ & $\begin{array}{l}.916^{\star \star \star} \\
.000 \\
15\end{array}$ & $\begin{array}{l}.891^{* *} \\
.000 \\
15\end{array}$ & $\begin{array}{l}.891^{\star *} \\
.000 \\
15\end{array}$ \\
\hline Distribution Volume & $\begin{array}{l}\text { Pearson Correlation Sig. (2-tailed) } \\
\text { N }\end{array}$ & $\begin{array}{c}.991^{\star *} \\
.000 \\
15\end{array}$ & $\begin{array}{l}.995^{\star \star} \\
.000 \\
15\end{array}$ & $\begin{array}{c}.995^{\star *} \\
.000 \\
15\end{array}$ \\
\hline Distribution Cost & $\begin{array}{c}\text { Pearson Correlation Sig. (2-tailed) } \\
N\end{array}$ & $\begin{array}{l}.812^{\star *} \\
.000 \\
15\end{array}$ & $\begin{array}{l}.825^{\star *} \\
.000 \\
15\end{array}$ & $\begin{array}{l}.825^{* *} \\
.000 \\
15\end{array}$ \\
\hline
\end{tabular}

To measure the efficiency level of the AMDK distribution, this study uses Data Envelopment Analysis (DEA) method. The analysis evaluates predetermined input and output variables whose correlation has been tested previously. The analysis is performed 
with the help of Frontier Analysis Software that makes it easier to calculate the efficiency level if each DMU hits $100 \%$ on its efficiency score. The areas that become the destination of the AMDK distribution channel are Jakarta, Bandung, Subang, Karawang, Bekasi, and Purwakarta. The result of the DEA is shown in Table 8.

Table 8 - DEA Result Using Frontier Analysis Software

\begin{tabular}{cccc}
\hline No & DMU & Efficiency & Condition \\
\hline 1 & Jakarta & $88.2 \%$ & Red/ not efficient \\
2 & Bandung & $99.3 \%$ & Amber/ not efficient \\
3 & Purwakarta & $100 \%$ & Green / Efficient \\
4 & Karawang & $82.9 \%$ & Red/ not efficient \\
5 & Subang & $63.8 \%$ & Red/not efficient \\
6 & Bekasi & $83.2 \%$ & Red/not efficient \\
7 & Tanggerang & $51.6 \%$ & Red/not efficient \\
\hline
\end{tabular}

To summarize the DEA result, there are three layers of condition, each with its own color code indicating different circumstances:

- Green, which means the project has the lowest risk and is on the right track towards the expected goal;

- Amber, that means the project may be risky if the issues it currently has is not handled immediately. Amber projects need extra attention;

- Red which means the project is high-risk because it derails from its track towards the goal. Management should undertake actions.

From the table above, it can also be concluded that the DMU that has the best efficiency level is Purwakarta. Aside from the fact that Purwakarta is production center so it requires the least amount of distribution cost, the volume of AMDK sales in this area is also high. Purwakarta has the best potential in local-brand marketing.

For Bandung, which is categorized into amber range or moderately risky if not handled properly, the exorbitant distribution cost has to be reevaluated. It could be overcome by increasing the volume of both sale and delivery.

For Jakarta, which is categorized into red range and considered inefficient, the root of its inefficiency is that this area applies zero-level distribution channel with low volume of sales, even though its customers are a few State-owned Enterprises (SOE) and government institutions. PJT II is supposed to contact a sub-distributor to act as an intermediary and manage the AMDK distribution in this area. The DMU of Karawang has the exact problem as Jakarta.

For Subang, Bekasi, and Tangerang, which are also categorized into red range and considered inefficient, the management needs to set a sales target for these areas. If the target cannot be met within a certain period of time, management needs to consider shutting down these DMUs or set up a contract with an external distributor to work with PJT II.

\section{MANAGERIAL IMPLICATIONS}

Improvement strategy is an effort used to raise the efficiency level of every DMU, so that they can reach an efficient state. Improvement strategy is essential for a company to fix poor allocation and management in its business activity. By implementing the strategy, the company can ensure every resource are properly managed to help the company achieve its goal.

Distribution efficiency improvement strategy for this AMDK industry is formulated using the DEA method with the help of Frontier Analysis Software. The DEA method provides the right tool to analyze whether the target of an efficiency level is met or not, and if not, what is the best way to improve it. The DEA result will show the actual efficiency level, which is the real value of the input and output variables of PJT II AMDK distribution. On the other hand, the DEA result will also show the targeted efficiency level for each variable: at what point does a variable need to be so that the DMU is at its most efficient state. 
Of all seven distribution areas, there are six distribution channels considered inefficient and in need of an improvement strategy: Jakarta, Bandung, Karawang, Subang, Bekasi, and Tangerang. According to the calculation result of the DEA method, each area requires different strategy based on its characteristic. However, they all have the same root of the problems and the following are a few improvement strategies that can be implemented to optimize the efficiency level in those areas:

- Maintaining the number of current agents and making sure that all of them stay in contract with PJT II. Maintaining the agents can help the AMDK product get recognized by more customers;

- Adding the number of agents to expand the market share;

- Reducing the volume of delivery to make it consistent with the order made by agents in order to avoid inventory pileup. The difference of quantity can be transferred to other nearer and more efficient distribution channel;

- Reducing the distribution cost, this is automatically done because the delivery volume is reduced.

This research focuses on the steps required to analyze the distribution channel of a local-scale AMDK company. A number of factors that can affect the distribution channel such as brand awareness, AMDK consumption pattern, and business competition are not explored in this paper because of the author's knowledge limitations.

\section{CONCLUSION AND RECOMMENDATIONS}

Efficiency analysis of AMDK distribution is as follows: (1) Distribution channel used by Perum Jasa Tirta II is zero-level (Producers to Customers) and one-level distribution channel (Producers to Retailers/Agents to Customers). The distribution areas which apply one-level channel are Jakarta, Bandung, Purwakarta, Karawang, Subang, Bekasi, and Tangerang. Distribution efficiency analysis is then conducted on the one-level distribution channel, using input (the number of agents, delivery volume, and distribution cost) and output (the volume of sales, revenue, and profits) variables. (2) Based on the Data Envelopment Analysis (DEA) with the help of Frontier Analysis Software, it is concluded that there is only one efficient distribution area which is Purwakarta, and the rest of other six areas are inefficient. (3) Strategies that can be implemented to improve the inefficient distribution channels are: (a) Reducing the volume of delivery and transfer the differences in quantity to other more efficient channels; (b) Increasing the volume of sales to avoid inventory pileup; (c) Increasing the number of retailers in the areas in which the distribution is not efficient.

The recommendations given by this paper to PJT II and for the next research regarding distribution efficiency are as follows: (a) To reducing the volume of delivery and transfer the differences in quantity to other more efficient channels; (b) To increase the volume of sales to avoid inventory pileup; and (c) To increase the number of retailers in the areas in which the distribution is not efficient

\section{REFERENCES}

1. Gaspersz, Vincent. 2005. Total Quality Management, Jakarta, PT. Gramedia Pustaka Utama.

2. Hidayati D. 2016. Strategi Komunikasi Pemasaran Usaha Skala Mikro (Micro Enterprise) Kub Bajrah Gunah Klampis Bangkalan Pada Produk Terasi, Petis and Kerupuk Ikan. Agriekonomika 5(1):104 -112.

3. Kotler P. Keller KL. 2009 Management Strategic Global Edition England (UK). Pearson Education.

4. Pratiwi I, Nandiroh S, Miski A. 2009. Analisis Efisiensi Distribusi Pemasaran Produk dengan Pendekatan Data Envelopment Analysis (DEA). Simposium Nasional RAPI 8 (1): $19-27$.

5. Ray S. 2004. Data Envelopment Analysis Theory and Techniques for Economics and Operations Research.University Press. The United States of America. Cambridge. 
6. Reinhard, S., Lovell, C. K. 2000. Environmental efficiency with multiple environmentally detrimental variables; estimated with SFA and DEA. European Journal of Operational Research, 121(2), 287-303.

7. Saladin D. 1996. Unsur-unsur Inti pemasaran and Manajemen Pemasaran. Mandar Baju. Bandung.

8. Shi P, Yan B, Shi S, \& Ke C. 2015. A decision support system to select suppliers for a sustainable supply chain based on a systematic DEA approach. Information Technology and Management, 16(1), 39-49.

9. Simamora, Bilson. 2003. Memenangkan Pasar dengan Pemasaran Efektif and Profitabel. PT. Gramedia Pustaka Utama. Jakarta.

10. Stanton, William. 1993. Marketing Principles. Erlangga. Jakarta.

11. Sulaeman A. 2015. Aspadin: Masyarakat Indonesia Habiskan 23,1 Miliar Liter Air Minum dalam Kemasan pada 2014 [Internet].[Diakses pada 10 Maret 2019]. Tersedia pada https://intisari.grid.id/read/0337452/aspadin-masyarakat-indonesia-habiskan-231-miliarliter-air-minum-dalam-kemasan-pada-2014.

12. Wibowo B, Rusdiana,Adiati U. 2016. Pemasaran Ternak Domba Di Pasar Hewan Palasari Kabupaten Indram- ayu. Agriekonomika 5(1): 85-93.

13. Van der Zaag, P.; Savenije, H.H.G. 2006. Water as an economic good: the value of pricing and the failure of markets. Research Report Series No. 1. 